\title{
CAN JUdGeS MAKE A DIFFERENCE? THE SCOPE FOR JUDICIAL DECISIONS on Climate Change IN NEW ZEALAND DOMESTIC LAW
}

\author{
Sir Geoffrey Palmer $Q C^{*}$
}

Political decision-making is at the heart of decisions on both mitigation and adaptation for climate change. While the norms are established internationally, they must be translated into domestic law in order to have bite. The making and enforcement of domestic law in many areas of environmental protection are frequently less than optimal. Legislation takes time to design and to enact. The details matter a great deal. Laggard governments around the world have been subjected to judicial review on their climate change policies. Furthermore, all statutes are subject to interpretation by courts. Administrators can and do make mistakes that are corrected by authoritative judicial interpretation. With particular emphasis on New Zealand law, this article will examine the degree to which judicial decisions can correct and encourage government policies on climate change and give them a "nudge" towards making them effective. The potential role of the Waitangi Tribunal will also be mentioned and the Parliamentary Commissioner for the Environment. The issue of whether constitutional protection for the environment, with application to climate change, could be useful will be canvassed.

* This is a slightly modified version of a keynote address delivered by the author to the 2 nd Pacific Climate Change Conference at the Museum of New Zealand Te Papa Tongarewa, Wellington, 21 February 2018. The author is grateful for helpful comments on an earlier draft from Dr Dean Knight.

Previous articles on this topic, or related to it, by the author include: "New Ways to Make International Environmental Law" (1992) 86 AJIL 259; "An International Regime for Environmental Protection" (1992) 42 Wash UJ Urb \& Contemp L 5; "The Implications of Climate Change for International Law and Institutions" (1992) 2 Transnatl L \& Contemp Probs 205; "The Earth Summit: What went Wrong at Rio?" (1992) 70 Wash ULQ 1005; "Climate Change in New Zealand: Is It Doom or Can We Hope?" (2015) 11 PQ 15; "New Zealand's Defective Law on Climate Change" (2015) 13 NZJPIL 115; "Global Society and the Challenges of Governance" (paper presented to New Zealand Centre for Global Studies, Waiheke, May 2016); "The Paris Climate Change Agreement and the Law" [2016] NZLJ 152; "Intergenerational Governance: problems of legislation" (2017) 13 PQ 68; and "Small Pacific Island States and the Catastrophe of Climate Change" in Petra Butler and Caroline Morris (eds) Small States in a Legal World (Springer, Switzerland, 2017) 3. 


\section{THE CONTEXT}

Legal systems in constitutional democracies adhere to the rule of law. This means that the authority of the state and its policies must be expressed by legal rules contained in legislation. The law "must be accessible and so far as possible intelligible, clear and predictable". ${ }^{1}$ The law is applied by the judiciary in cases that are brought before the courts. It is applied independently of those who made the law and of those responsible for executing the laws. In New Zealand Parliament makes the law, the government is responsible for its administration and the courts interpret what it means in contested cases. These arrangements constitute an essential feature of liberal democratic government. They are designed to preserve the freedom of the individual as far as practicable and to keep the power of the state within limited bounds.

In the age of the Anthropocene, where human activity threatens to change irreparably the environment in which we live, there exist serious challenges to the traditional law-making techniques of the liberal democratic state. While not confined to climate change, these challenges apply acutely to that phenomenon. ${ }^{2}$ The judgment expressed to the United States Senate in 2013 concerning the security implications of climate change is widely supported by scientific research. Dr James Clapper, in testimony to the Senate, stated that "[e]xtreme weather events (floods, droughts, heatwaves) will increasingly disrupt food and energy markets, exacerbating state weakness, forcing human migrations, and triggering riots, civil disobedience and vandalism."

Combatting climate change requires actions on two fronts: the reduction of greenhouse gas emissions and taking steps to adapt to changes that will occur. The development of such policies involves complex interaction between international norms, such as those contained in the Paris Agreement of 2015, and domestic law. ${ }^{4}$ No nation state alone created climate change and none alone can stop it. International cooperation is essential for success. Since the first authoritative report that foretold the threats posed by climate change was published in 1990, there have been many false starts to combat the problem both internationally and domestically. ${ }^{5}$ Coherent policy parameters that will succeed in avoiding the threats listed above remain to be put in place. It is quite possible, even likely

1 Tom Bingham The Rule of Law (Allen Lane, London, 2010) at 37.

2 The field of international environmental law is replete with examples. See Jonathan C Carlson, Geoffrey Palmer and Burns H Weston International Environmental Law and World Order: A Problem-Oriented Coursebook (3rd ed, West Academic Publishing, St Paul, 2012).

3 James R Clapper Statement for the Record: Worldwide Threat Assessment of the US Intelligence Community (Senate Select Committee on Intelligence, 12 March 2013) at 9.

4 Paris Agreement (opened for signature 22 April 2016, entered into force 4 November 2016).

5 JT Houghton, GJ Jenkins and JJ Ephraums (eds) Climate Change: The IPCC Scientific Assessment (Cambridge University Press, Cambridge (UK), 1990); and WJ McG Tegart, GW Sheldon and DC Griffiths (eds) Climate Change: The IPCC Impacts Assessment (Australian Government Publishing Service, Canberra, 1990). 
as matters stand currently, that international efforts to combat climate change will not succeed in preventing many of the deleterious consequences that have been predicted.

The challenge of climate change and the prospect of failing to combat it effectively raise constitutional questions of the first order in importance. There will be few lifeboats available. There has been a strange unthinking and unrealistic character to the debate since the climate change issue first arose as a political issue. While climate sceptics, who doubted the threat, have largely been vanquished, the failure to make adjustments to policy both nationally and internationally in a timely fashion has been surprising, given the evidence. Policymakers have discounted the future in favour of the present, not wishing to face up to the real and adverse political consequences that effective action will require. The difficulty in such a stance lies in the fact that sudden adjustments to policy will be much harder to manage than those that can be instituted over a longer time frame. And the time for adjustments is rapidly shrinking.

Policy frameworks are governed by constitutions. New Zealand does not have a constitution in the sense that other countries do. We rely on statutes passed by Parliament and the common law. Parliament can pass whatever statutes it likes whenever it likes. The restraints are few. The seeming surface simplicity of these arrangements is attractive to governments who wish for maximum flexibility. We are one of three countries in the world without a codified, written constitution. ${ }^{6}$

One largely unexplored aspect of climate change lies in its potential to force the revision of many fundamental and long-accepted methods of conducting government and the organisation of its institutions. The Four Horsemen of the Apocalypse in the Book of Revelation were pestilence, war, famine and death. Climate change has the capacity to produce those conditions to a worrying extent in the future. We underestimate at our peril the challenges that it will bring and that it has brought already. ${ }^{7}$

Ensuring that the institutions of government both domestically and internationally can adjust to meet those challenges poses a formidable set of issues. These issues, however, cannot be solved by New Zealand and they will depend upon levels of international cooperation as yet not achieved. Endless further iterations of the Paris Agreement will be necessary before substantial progress is made. As I have written elsewhere, I am not sanguine that the mechanisms for making international law and enforcing it effectively are adequate to allow us to be confident that climate change can be properly addressed. ${ }^{8}$

6 The United Kingdom and Israel are the others. See also Constitutional Advisory Panel New Zealand's Constitution: A Report on a Conversation (November 2013).

7 Amitav Ghosh The Great Derangement: Climate Change and the Unthinkable (University of Chicago Press, Chicago, 2017).

8 Palmer "Small Pacific Island States and the Catastrophe of Climate Change", above n *, at 16. 
In June 2017 in Paris the Global Pact for the Environment was unveiled and it is a powerful document that would remedy many difficulties with the international law for the environment if it were to become binding. ${ }^{9}$ That does not seem an immediate possibility. ${ }^{10}$ The bulk of this article addresses New Zealand's domestic legal situation and the role of the courts within it. The wider framework, however, needs to be optimally designed so that it can endure over time and is not the subject of sudden policy lurches due to changes of government.

\section{THOMSON v THE MINISTER FOR CLIMATE CHANGE ISSUES}

On 2 November 2017 Mallon J in the High Court delivered a notable and careful judgment in Thomson $v$ The Minister for Climate Change Issues. ${ }^{11}$ This proceeding for judicial review was brought by a law student who was concerned at the Key-English Government's response to climate change and the adverse consequences the policies may visit upon future generations. Mallon $\mathbf{J}$ reviewed extensive expert scientific affidavit evidence and the relevant elements of the international framework by which New Zealand is bound. She also reviewed New Zealand's domestic legislation and analysed the law in light of New Zealand's international obligations.

The case was filed in court in November 2015. Normally judicial review cases are dealt with promptly but for good reasons this one took longer. The preparation of expert scientific evidence on both sides was one cause. Further, discovery of documents was a more complex process than usual given the complexity of the target issues. The case was argued on 26, 27 and 28 June 2017. The judgment was delivered on 2 November 2017, after a new Government had been installed that had announced different climate change policies from those of the Government whose actions were the subject of the action for judicial review.

While this development made the task of the Judge easier, it also reduced the significance of the decision itself to some extent. Had there not been a change of government following the 2017 general election, the decision would have had greater impact. The Coalition of Labour and New Zealand First,

9 Environment Commission of the Club des Juristes Draft Project: Global Pact for the Environment (24 June 2017).

10 Articles 23-24.

11 Thomson v The Minister for Climate Change Issues [2017] NZHC 733, [2018] 2 NZLR 160. There have been a handful of other cases in New Zealand that have touched upon climate change: West Coast Ent Inc v Buller Coal Ltd [2013] NZSC 133, [2014] 1 NZLR 32 (the relevance of climate change to granting a resource consent under the Resource Management Act 1991); Meridian Energy Ltd v Central Otago District Council [2011] 1 NZLR 482 (HC) (it is not necessary to discuss climate change every time in Resource Management Act cases); Imported Motor Vehicle Industry Assoc Inc v Minister of Transport HC Wellington CIV-2011-485-1972, 1 December 2011 (a challenge to emissions standards for imported used light petrol powered vehicles); and New Zealand Climate Science Education Trust v National Institute of Water and Atmospheric Research Ltd [2012] NZHC 2297, [2013] 1 NZLR 75 (challenging NIWA science advice to the Government that New Zealand had experienced a warming trend). 
with the support of the Green Party, announced after the election a new target of zero carbon by 2050, twice as ambitious as the previous target of the outgoing Government. ${ }^{12}$

The first cause of action concerned whether the Minister was required to review the 2050 target for the reduction of greenhouse gases gazetted on 31 March 2011 under s 224 of the Climate Change Response Act 2002. That target required a 50 per cent reduction in emissions, using 1990 as a baseline. The plaintiff argued that this needed to be revised in light of the Fifth Assessment Report (AR5) of the Intergovernmental Panel on Climate Change (IPCC), published in stages between September 2013 and November 2014. This was the most up to date assessment of the science and indicated a rather more serious situation than the previous report in 2007.

On this cause of action the issue before the Judge was one of statutory interpretation. This required close construction of both ss 224 and 225 of the Climate Change Response Act. The Judge was clear that the obligation to review did not arise under s 225(3), but did it arise under s 224? The Minister had a statutory discretion to review the target, but was the Minister obliged to do so? The Judge thought she was.

The two sections of the Act provided for two distinct processes for setting targets. The two provisions produce instruments of different legal qualities. The first, under s 224 , is a notice in the Gazette indicating that New Zealand sets a target. The second produces a regulation, a form of subordinate legislation that has legal effect. Section 224 involves more elaborate processes within the government and requires public consultation on the face of the statute. It is not evident why two such provisions are either necessary or desirable.

\section{Gazetting of targets}

(1) The Minister must set a target.

(2) The Minister responsible for the administration of the Act may set a target, or amend or revoke an existing target, at any time.

(2A) Before the Minister sets, amends, or revokes a target, the Minister must consult, or be satisfied that the chief executive has consulted, persons (or their representatives) that appear to the Minister or the chief executive likely to have an interest in the target.

12 The following footnote provided by the Judge at [72], n 77 is instructive as it relied on political developments reported in the media: "The Zero Carbon Act was a Green Party election priority: Green Party 'Climate Protection Plan: For a better future' (13 September 2017) <www.greens.org.nz>. The Rt Hon Jacinda Ardern has said following the election that climate change will be a priority for her government, including a Zero Carbon Act: Henry Cooke 'Live: Labour-led government to make climate change a priority' (20 October 2017) Stuff <stuff.co.nz>; 'NZ First, Green Party, Labour coalition deals revealed' (24 October 2017) Stuff <stuff.co.nz>; and Karl Mathiesen 'Jacinda Ardern commits New Zealand to zero carbon by 2050' (20 October 2010) Climate Home News <www.climatechangenews.com>." 
(3) As soon as practicable after setting, amending, or revoking a target under this section, the Minister must-

(a) publicly notify the target or revocation of the target in the Gazette; and

(b) make the target or revocation of the target publicly accessible via the Internet site of the department of the chief executive.

(4) To avoid doubt, a Gazette notice under this section is neither a legislative instrument nor a disallowable instrument for the purposes of the Legislation Act 2012 and does not have to be presented to the House of Representatives under section 41 of that Act.

(5) To avoid doubt, any number of targets may be set using the process under this section.

\section{Regulations relating to targets}

(1) The Governor-General may, by Order in Council made on the recommendation of the Minister, make regulations setting a target.

(2) Before recommending the making of an Order in Council under subsection (1), the Minister must consult, or be satisfied that the chief executive has consulted, persons (or their representatives) that appear to the Minister or the chief executive likely to have an interest in the order.

(3) The Minister-

(a) must review the target following publication of any Intergovernmental Panel on Climate Change Assessment Report or report of a successor agency; and

(b) may at any time recommend to the Governor-General the setting of a target, or amendment or revocation of a target, having regard to the following matters:

(i) any Intergovernmental Panel on Climate Change Assessment Report or report of a successor agency:

(ii) any other matters the Minister considers relevant.

(4) To avoid doubt, any number of targets may be set using the process under this section.

People may wonder why these provisions do not altogether seem consistent with one another. The answer lies in the extent of amendments made to the Climate Change Response Act since its enactment in 2002. The most important of these were the result of changes of government policy, including changes of government. Section 224 was inserted by the Climate Change Response (Emissions Trading) Amendment Act 2008. Section 225 resulted from the Climate Change Response (Moderated Emissions Trading) Amendment Act 2009. There were also amendments to the provisions in 2011 and in 2013.

The learned Judge states at [94] of her judgment that in her view what is express under s 225(3) is implicit in s 224(2). Since the IPCC reports provide the most up to date scientific consensus on 
climate change she considered "the publishing of a new IPCC report requires the Minister to consider whether a target set under s 224 should be reviewed". ${ }^{13}$ The Minister was obliged to consider whether the new report: ${ }^{14}$

... materially alters the information against which an existing target was set. If it does, a review of the

target must be undertaken. That review may or may not lead to a decision to amend an existing target or

to set additional targets, depending on the outcome of the review process undertaken.

The next point was whether the target was consistent with the new report; it was common ground that it was consistent with the previous report. There was expert evidence for the defendant that "it is also consistent with the AR5 and at the more ambitious end of the range". ${ }^{15}$ The Judge pointed out that this "counts against any remedy requiring the Minister to consider whether the 2050 target ought to be reviewed in light of the AR5". ${ }^{16}$ She indicated that had it not been for the change of government it may have been appropriate to seek further submissions from the parties in order "to reach a concluded view on whether it would have been appropriate to direct the Minister to review the target in light of the AR5". ${ }^{17}$

In other words, there was now no need for the Judge to decide the matter and she did not do so. The issue was rendered moot by the change of policy announced by the new Government.

The second cause of action put forward by the plaintiff revolved around the 2030 target communicated under the Paris Agreement. This target required a 30 per cent reduction in greenhouse gas emissions by 2030, using 2005 as baseline. This was New Zealand's Nationally Determined Contribution (NDC) as required by the Paris Agreement. It had also been advanced to the United Nations Framework Convention on Climate Change negotiations in July 2015 as New Zealand's Intended Nationally Determined Contribution (INDC) target.

The case for the plaintiff was that the defendant had failed to take into account the costs of dealing with the adverse effects of climate change in a "business as usual" situation. ${ }^{18}$ Second, that Tokelau as a dependant territory was particularly vulnerable. ${ }^{19}$ And third, that according to the scientific

13 Thomson, above n 11, at [94].

14 At [94]. Although the issue does not appear to be raised in Thomson, the government may be able to rely on the royal prerogative in respect to some climate change issues, especially when they touch upon compliance with international obligations.

15 At [97].

16 At [97].

17 At [97].

18 At [99].

19 At [99]. 
consensus both the extent and speed of the INDCs fell short of what is required to stabilise greenhouse gas concentrations. ${ }^{20}$

The reasoning of the Judge on this cause of action engaged with the key policy difficulty for courts in the climate change arena. She addressed the question of whether the issues were justiciable, in the sense of whether it was an appropriate case for a court to decide. The defendant argued that it was not. The Judge then examined decisions from other jurisdictions where climate change policy had been adjudicated upon. The Judge discussed cases from the United States, Oregon, Canada, the United Kingdom and the Netherlands. ${ }^{21}$ These cases showed that there was a propensity to consider the climate change issue justiciable; there was standing to bring suit in some cases and in the United Kingdom case relief had been granted to ensure steps were taken to implement the legal obligations of a directive concerning emission limits of nitrogen dioxide in particular zones.

The Judge found that "these cases illustrate that it may be appropriate for domestic courts to play a role in Government decision making about climate change policy". ${ }^{22}$ She noted the claims had all succeeded to some extent, with the exception of the Canadian case, and observed that: ${ }^{23}$

The courts have not considered the entire subject matter is a "no go" area, whether because the state had entered into international obligations, or because the problem is a global one and one country's efforts alone cannot prevent harm to that country's people and their environment, or because the Government's response involves the weighing of social, economic and political factors, or because of the complexity of the science.

The Judge resisted the submission that there could be no review on the issues in the case: ${ }^{24}$

The importance of the matter for all and each of us warrants some scrutiny of the public power in addition to accountability through Parliament and the General Elections. If a ground of review requires the Court to weigh public policies that are more appropriately weighed by those elected by the community it may be necessary for the Court to defer to the elected officials on constitutional grounds, and because the Court may not be well placed to undertake that weighing.

20 At [99].

21 Massachusetts v Environmental Protection Agency 549 US 497 (2007); Juliana v United States of America DC Eugene, Oregon 6:15-cv-1517-TC, 8 April 2016, upheld on review in Juliana v United States of America 217 F Supp 3d 1224 (D Or 2016); Friends of the Earth v Canada (Governor in Council) 2008 FC 1183, [2009] 3 FC 201; $R$ (on the application of ClientEarth) $v$ Secretary of State for the Environment, Food and Rural Affairs [2015] UKSC 28, [2015] PTSR 909; and Urgenda Foundation v The State of the Netherlands (Ministry of Infrastructure and the Environment) DC Hague C/09/456689/HA ZA 13-1396, 24 June 2015.

22 Thomson, above $\mathrm{n} 11$, at [133].

23 At [133].

24 At [134] 
But in the Judge's view this was not a case where the Court should on these facts intervene. She did not find herself able to hold that the INDC or the NDC were outside the proper bounds of the Minister's power because of the manner in which the economic modelling was undertaken.

Nor was she persuaded on the facts that the argument about Tokelau had merit. It was clear, she held, that New Zealand had Tokelau in mind when deciding whether to ratify the Paris Agreement and it intended to assist Tokelau. The impact on Tokelauans was a mandatory relevant consideration for the Government to consider but she was not persuaded this meant that New Zealand's NDC target "needed to be consistent with a $1.5^{\circ} \mathrm{C}$ target" as the plaintiff had argued. ${ }^{25}$

Neither did the third argument succeed; the nature of the NDC involved the balancing of a number of competing factors. The fact that a differently constituted government may have balanced the competing factors differently did not mean the NDC was outside the Minister's power.

The third cause of action was that the NDC decision of the Minister was unreasonable and irrational. The Judge was not persuaded that the Minister had the wrong global temperature aim in mind when setting the NDC. The $1.5^{\circ} \mathrm{C}$ limit was to be subjected to further international dialogue. Nor was she persuaded that: ${ }^{26}$

... the NDC decision was unreasonable in a judicial review sense because the costs of deeper targets are comparatively small and there are other costs associated with delay. How the costs considerations are appropriately balanced is properly for the Executive to decide, especially as the international legal framework does not stipulate how a country is to determine this.

The argument that the 2030 target was not consistent with the 2050 goal fared better but did not prevail. Here there was evidence from duelling expert climate change science professors. While the Judge accepted that New Zealand's 2030 target was somewhat less ambitious than its 2050 target that did not mean it was inconsistent with the global temperature agreement under the Paris Agreement, nor that it was inconsistent with New Zealand's international obligations or was outside the Minister's power to make. ${ }^{27}$

The learned Judge characterised her own result at the conclusion of her judgment. The Minister was required to turn her mind to whether there had been any material change between the AR4 and AR5 that was relevant to the 2050 target, but this did not occur. But the cause of action was overtaken by events in that the new Government was intending to set a new target. Earlier in her judgment the Judge pointed out the same result could have been reached even if the decision had been reconsidered, such was the discretionary space available to the decision-maker.

\footnotetext{
25 At [157].

26 At [168].

27 At [176].
} 
The application for judicial review was dismissed and the Judge expressed her preliminary view that the costs should lie where they fall. It is not uncommon in judicial review proceedings for the courts to assert their power to intervene, thus keeping the capacity of the court alive for the future, but to find on the facts that intervention is not appropriate on the facts of the case before the court. This can be regarded as good judicial statecraft. It emphasises to decision-makers that they need to go about making such decisions carefully and properly in order to avoid litigation.

\section{WHAT CAN JUDICIAL REVIEW CONTRIBUTE TO CLIMATE CHANGE POLICY?}

The foregoing account gives a flavour of the approach the New Zealand courts are likely to bring to climate change issues in judicial review proceedings. ${ }^{28}$ While the decision was one at first instance and lacks the benefit of refinements that may result from an appellate decision, it was careful, orthodox and prudent. It was the most significant New Zealand judicial decision on the topic of climate change since it involved a direct challenge to government policy. The decision is a fair and accurate indication of what to expect from the courts. While the judicial review of administrative action has expanded greatly over the past 50 years, there are confined limits within which the judges must operate.

Obviously, it is important that governments are required to observe the legal boundaries laid down in statute and that they follow proper process. Legal authority for actions taken by government must be established; actions have to be authorised by law. But, as Thomson illustrates, too much cannot be expected from judicial review in an area like climate change that exhibits a difficult mix of national and international obligations, hard science, high politics and many uncertainties. ${ }^{29}$

The most significant feature to emerge from the judgment is the margin of discretion available to ministers in an area like climate change. Where discretion has been entrusted to ministers, the courts are going to be wary before they intervene and hold that the discretion has been wrongly exercised and is therefore unlawful. This particular Judge and New Zealand judges in general will be reluctant to substitute their own policy views for those of ministers and they will be scrupulous to avoid doing that.

28 Many statutes provide for appeal against various types of government decisions. The grounds for appeal can be wide or narrow depending upon the statute. For example, under s 145 of the Climate Change Response Act there is a right of appeal for an affected person to the District Court from the review of a decision by the Environmental Protection Agency made under pts 4-5. Under this section, the court "may confirm, reverse, or modify the decision appealed against". Appeals involve adjudication on the merits of a decision (unless they are restricted to points of law), whereas judicial review is concerned with the legality of a decision: Philip A Joseph Constitutional \& Administrative Law in New Zealand (4th ed, Thomson Reuters, 2014) at 863.

29 The science is particularly difficult to litigate. See Laura Hardcastle "Can't See the Science for the Solicitors: Judicial Review of Scientific Research in Light of NIWA's Case" (2014) 12 NZJPIL 291. 
There is a tendency in the environmental arena, both in New Zealand and overseas, to bring legal actions where groups are convinced government policy is inadequate in the hope that the decisions will be overturned by the court. I know that litigation on climate change issues was seriously contemplated in several quarters against the previous New Zealand Government, but the timing of international negotiations was often an obstacle. Such litigation is often aimed at a political goal that has not been capable of achievement by political representations. I am not suggesting that there is anything improper in such proceedings. There are instances where governments will have approached issues in the wrong way, not in accordance with the requirements of the statute or have been influenced by improper considerations. In such cases decisions can be reconsidered and different outcomes may result.

There does exist something of an international movement to encourage climate change litigation. It is aided by the fact that environmental laws generally are not well enforced and litigation opportunities for private enforcement do exist. Environmental illegality can affect many people. For example, a public inquiry was held after the widespread outbreak of gastroenteritis in Havelock North in August 2016, with more than 5,000 people falling ill following the confirmation of the presence of E coli in the water supply. The inquiry found grave weaknesses in the law, policy and administration that required urgent and early action. ${ }^{30}$ It is likely that as time progresses the courts will be more deeply involved in environmental issues than they are now. A recent book concerning a novel public interest law firm aimed at environmental issues deserves attention. ${ }^{31}$ It argues that the firm ClientEarth exists to give the environment a legal voice. It uses litigation to open the courts to the environmental concerns of citizens. The firm has won some significant victories in Europe, the United States and elsewhere. It successfully attacked government policies in the courts. Many of the legal weapons available in other countries are not available here because of New Zealand's existing constitutional arrangements.

As the law stands, at least in the New Zealand context, it will not often occur that major climate change decisions of government will be quashed. The expense of bringing judicial review litigation in the High Court is substantial. The burden of costs awarded where the party is unsuccessful makes this form of litigation more uncertain than most, especially because the remedies are discretionary. There are, of course, benefits that derive from what the Crown Law Office booklet for public servants aptly named The Judge Over Your Shoulder. ${ }^{32}$ The threat of litigation encourages decisions on important issues to be made after careful consideration on the basis of extensive advice. The

30 Department of Internal Affairs Report of the Havelock North Drinking Water Inquiry: Stage 2 (December 2017) at 232-235.

31 James Thornton and Martin Goodman Client Earth (Scribe, London, 2017).

32 Crown Law Office The Judge Over Your Shoulder: Judicial Review of Administrative Decisions (1989). One can find no reference to this or any successor on the present Crown Law Office website $<w w w . c r o w n l a w . g o v t . n z>$. 
documents will be trawled through by litigants to see what holes there are in what has been decided. The Official Information Act 1982 is a significant tool for that purpose.

The New Zealand public service has many highly competent officials and ministers in this country do not tend to make reckless decisions. It is also true that the judges are not trained in policy analysis and the judicial process is not well suited for the making of policy decisions. ${ }^{33}$ What is appropriate for judicial decision and what is not are real issues in the climate change arena, as Mallon J's judgment has well illustrated.

Slowly and gradually over time the factors to which the judges will respond have widened. Yet they are more likely to be persuaded to intervene on matters of injustice done to individuals by poor process where, for example, the principles of natural justice have not been applied. Or if mistakes in statutory interpretation have been made in the decision, the chances of intervention increase. The variability and unpredictability of judicial review, however, makes advising on the prospects of success difficult. On matters of high government policy, into which category much of climate change policy falls, the prospects for success are always going to be harder. Influencing government policy is not usually best achieved by making an application for judicial review. It is very much a last resort and requires deep pockets.

Where the courts are strong is applying the law and determining what is legal and what is not. At the margins, however, this line can be unpredictable. The most likely judicial review application to succeed will be where decision-makers have not properly applied the statute. Statutory interpretation is a vast field of law and the cardinal rule of statutory interpretation in New Zealand is to be found in s 5 of the Interpretation Act 1999:

\section{$5 \quad$ Ascertaining meaning of legislation}

(1) The meaning of an enactment must be ascertained from its text and in the light of its purpose.

(2) The matters that may be considered in ascertaining the meaning of an enactment include the indications provided in the enactment.

(3) Examples of those indications are preambles, the analysis, a table of contents, headings to Parts and sections, marginal notes, diagrams, graphics, examples and explanatory material, and the organisation and format of the enactment.

"Context" is also important and will be added by a measure presently progressing through Parliament. ${ }^{34}$ Two points need to be emphasised. Words matter a great deal. Close and careful analysis

33 Some difficult issues are involved in the relationship of lawyers, legislation and policy. See Geoffrey Palmer "The Law Reform Enterprise: Evaluating the Past and Chartering the Future" (2015) 131 LQR 402 at 413.

34 Clause 10 of the Legislation Bill 2017 (275-1) adds the words "and its context" at the end of s 5(1) reproduced in the text. 
of the words in any statutory provision needs to be carried out. Second, the architecture of modern complex statutes such as the Climate Change Response Act or the Resource Management Act 1991 requires examination of the entire statute to ensure that all elements of the statute are brought to bear upon the issue concerned. The purpose of the legislation, interpreted in its full social, cultural, economic and political context, matters as much as the words. The strongest ground will always be that the statute does not permit the construction it has been given. That is to say, the decision is outside the power that Parliament has conferred or ultra vires. ${ }^{35}$

The grounds of judicial review are many and they may suggest at first blush that judges have a whole range of powers to intervene on government decision-making. They do in theory, but not so much in practice. Beyond issues of bare legality, the decision-maker must take into account all relevant considerations and must not take into account irrelevant considerations. The decision must not be the subject of bias. The decision must not have been predetermined. It must be exercised in most cases in accordance with the principles of natural justice, themselves rather elaborate. Naked abuse or wrongful use of power will be caught by applications for judicial review, but in reality in New Zealand matters are more nuanced and seldom can an administrative law smoking gun be discovered in a decision.

The threshold to be met for judicial review to succeed is high. Judicial review is not simple and the basis of the doctrine beyond the principle of ultra vires is often unclear. While it was put on a statutory basis by the Judicature Amendment Act 1972 (now incorporated with some revisions in the Judicial Review Proceedings Act 2016), in essence judicial review is a common law doctrine that depends for its development upon decisions of the judges and the doctrine of precedent.

Expansion is slow because the judges are concerned not to overstep what is considered in New Zealand as the appropriate judicial role. What is sometimes labelled judicial activism in this field has not been evident in New Zealand and is not likely to be. Ministers have unlimited access to the legislative machinery to change the law should they feel threatened by judicial review of their actions. It is a sensitive line the judges tread. And not all judges feel familiar enough with the institutions and processes of government to have the confidence to intervene.

The following list of grounds for judicial review has been gathered together from various legal texts and they should not be regarded as authoritative, but merely illustrative: ${ }^{36}$

- $\quad$ illegality, exceeding the powers given or making errors of law;

- improper purpose;

- taking into account irrelevant considerations;

35 The leading textbook on statutory interpretation is Ross Carter Burrows and Carter Statute Law in New Zealand (5th ed, LexisNexis, Wellington, 2015).

36 The most recent legal text on the subject of judicial review covers 1,300 pages: Matthew Smith New Zealand Judicial Review Handbook (2nd ed, Thomson Reuters, Wellington, 2016). 
- failing to take into account relevant considerations;

- making serious errors of fact;

- $\quad$ applying a predetermined policy;

- $\quad$ acting under dictation from elsewhere;

- $\quad$ failing to consult where consultation is required;

- acting unfairly, particularly in relation to the manner in which the decision was reached;

- breaching the rules of natural justice;

- acting under an invalid delegation of power;

- making a decision that no reasonable decision-maker could have arrived at;

- where the decision-maker has bias, such as a financial interest in the decision; and

- procedural and sometimes substantive legitimate expectations.

These grounds for judicial review have many reported judicial decisions exploring their parameters. The grounds do overlap to some degree. Administrative law in New Zealand has developed since the 1972 Act, but it lacks both coherence and simplicity. It is difficult to predict whether judges will intervene in particular cases and there is a worrying variability about whether they will or will not. This has led to serious efforts to analyse the theoretical underpinnings of judicial review. ${ }^{37}$ That is not to say judicial review lacks utility. Keeping decision-makers within the bounds of their legal powers is important. Having statutes authoritatively interpreted by independent judges is a protection. But judges in New Zealand should not be regarded as alternative policy-makers who can readily be persuaded to review decisions on their merits and substitute their own decisions for those to whom the decision has been entrusted by law. If there were constitutional provisions about the environment in an entrenched Bill of Rights the situation would be different as the next section of this article suggests.

Climate change policy has to be regarded as a matter of high policy. The principal elements of the policy will be difficult to subject to judicial review, especially by direct challenges to government policy. Unfair application of the rules in particular cases will attract judicial attention, however. While judicial review will not be impotent for breaches of statutes or clearly illegal decisions, the scope for improving the quality of climate change stewardship via the courts is limited. That is the main message I wish to convey about New Zealand law as matters now stand. Here and there the courts may give the policy a nudge, but do not expect quantum leaps forward in climate change policy to emanate from the New Zealand courts. Having said that, there is greater scope for judicial decisions on climate change adaptation (as opposed to emissions) since that issue is primarily dealt with under the Resource Management Act.

37 Dean R Knight Vigilance and Restraint in the Common Law of Judicial Review (Cambridge University Press, Cambridge (UK), 2018). 


\section{WOULD IT MAKE A DIFFERENCE IF WE HAD A WRITTEN CONSTITUTION WITH AN ENVIRONMENTAL RIGHT?}

New Zealand does not have a written, codified constitution. It is one of only three countries without one. Parliament can make any law it likes. There are few limits except triennial elections and public opinion. The New Zealand Bill of Rights Act 1990 is not superior law. It can be overridden by a statute. It has been overridden in this way on 37 occasions since it has been in existence. ${ }^{38}$

In our 2016 book A Constitution for Aotearoa New Zealand Andrew Butler and I proposed that the existing Bill of Rights be made part of a superior law constitution so it is binding upon Parliament and so other statutes must be in conformity with it. ${ }^{39}$ We also proposed some additional rights, including an environmental right. We believe that the environment needs protection up there along with the human rights that are already protected by the current New Zealand Bill of Rights Act. So, our proposed draft Constitution in 2016 included such a guarantee.

There has been over the last 20 years a rapidly growing international movement to connect the strong developments in human rights law with the magnitude of the global environmental crisis. More than 80 nations have enacted constitutional reforms to provide recognition for environmental rights. ${ }^{40}$ We believe the time has come to follow that trend in New Zealand. The model we chose in our first draft of Constitution Aotearoa was based on the widely admired South African Constitution. There were fewer reported judicial decisions on the environmental provision than we expected. We concluded that the right had not produced an avalanche of litigation.

Our aim was to ensure that people can enjoy an environment that is not harmful to their health or well-being and to protect the environment for the benefit of present and future generations by ensuring that economic development is sustainable. Among other things, constitutional protection means in this context that environmental standards could not be reduced by a small majority in the House of Representatives.

We were persuaded by explicit consultations we conducted with environmental organisations and the submissions we received, that our draft of the environmental right in the 2016 book needed to be revised and strengthened. We received almost no submissions explicitly opposing the right, and we received 440 submissions from the public. In our 2018 version we have placed more emphasis on

38 Geoffrey Palmer "What the New Zealand Bill of Rights Act Aimed to Do, Why it did not Succeed and How it can be Repaired" (2016) 14 NZJPIL 169 at 201-208.

39 Geoffrey Palmer and Andrew Butler A Constitution for Aotearoa New Zealand (Victoria University Press, Wellington, 2016). The proposal for the addition of an environmental right to an entrenched Bill of Rights was developed further in Geoffrey Palmer and Andrew Butler Towards Democratic Renewal: Ideas for constitutional change in New Zealand (Victoria University Press, Wellington, 2018) at 163-166.

40 David R Boyd The Environmental Revolution: A Global Study of Constitutions, Human Rights, and the Environment (UBC Press, Vancouver, 2012). 
conservation and biodiversity values. There is also more emphasis on ecological issues and Māori values. The earlier draft was too anthropocentric and it needed to lean in the direction of giving the environment itself legal rights, as was done in the recent legislation concerning the Whanganui River. ${ }^{41}$ There needs to be less space for economic development to trump environmental values. Here is the provision we have drafted for the 2018 book: ${ }^{42}$

\section{Environmental right}

(1) Everyone has the right-

(a) to an environment that is not harmful to their health or well-being; and

(b) to have the environment protected, for the benefit of present and future generations, through reasonable legislative and other measures that-

(i) prevent pollution and ecological degradation:

(ii) promote conservation and biodiversity:

(iii) secure ecologically sustainable development and the use of natural resources in a manner that is managed to maintain the equilibrium of the environment:

(iv) include kaitiakitanga, which is the exercise of guardianship by the tangata whenua of an area in accordance with tikanga Māori in relation to natural and physical resources.

(2) The Commissioner for the Environment may, if the Commissioner considers it appropriate to do so,-

(a) conduct litigation to safeguard the rights contained in this Article:

(b) intervene in litigation in which issues relating to those rights are raised.

We believe a provision of the type we propose would be of value in preserving and enhancing the quality of New Zealand's environment. Of course, what is proposed is a significant change from the existing law and empowers the judiciary with new tools. One of our submitters argued that such a right would result in the following benefits:

- the enactment of stronger environmental laws;

- the provision of a safety net for gaps in the statutory environmental laws;

- $\quad$ raising the profile of environmental protection as compared to competing interests;

- creating opportunities for better access to justice and accountability for environmental decisions; and

- contributing to better environmental performance.

How much difference such a right would make would depend upon the context in which the issue arose. One test is to ask whether the result of the case in front of Mallon J would be any different if

41 See Te Awa Tupua (Whanganui River Claims Settlement) Act 2017.

42 Palmer and Butler Towards Democratic Renewal, above n 39, at ch 19, Constitution Aotearoa, art 26. 
such a provision were part of the law. Certainly, such a provision would strengthen the case for the plaintiffs. But could it be confidently predicted that the measures adopted by the previous Government were not "reasonable legislative ... measures" given the complex overlay of international obligations in the climate change space? Such a right would be likely to have considerable weight in improving water quality in domestic law but on climate change perhaps not so much. On the other hand, inactivity in light of clear evidence on environmental threats could attract a constitutional remedy from the courts.

There are important human rights issues bound up in environmental protection. The future of New Zealand will be inextricably bound up with the global environmental problems that threaten to overwhelm the planet. The challenges these problems pose to the development of public policy in New Zealand are formidable.

Climate change is one of the issues, but it is not the only one: water quality, the health of the oceans and acidification, the disposal of waste, loss of top soil, air quality and chemical pollution are others. In such circumstances it may be prudent to set out some constitutional markers to ensure that New Zealand's standards of environmental protection are enhanced and not reduced, as is the current trend.

Restraints will be placed on the capacity of policy-makers to breach the constitutional guarantees. The public will know what the bottom lines are. Ministers and Members of Parliament will be bound by the Constitution and so will the judges. In other words, for such constitutional rights to be meaningful they must be enforceable.

In May 1994, an international group of experts on human rights and environmental protection convened at the United Nations in Geneva and drafted the first declaration of principles on human rights and the environment. ${ }^{43}$

Part I of that document contains a succinct statement of the principles: ${ }^{44}$

1. Human rights, an ecologically sound environment, sustainable development and peace are interdependent and indivisible.

2. All persons have the right to a secure, healthy and ecologically sound environment. This right and other human rights, including civil, cultural economic, political and social rights, are universal, interdependent and indivisible.

3. All persons shall be free from any form of discrimination in regard to actions and decisions that affect the environment.

43 Fatma Zohra Ksentini Report of the Special Rapporteur on Human Rights and the Environment UN Doc E/CN.4/Sub.2/1994/9 (6 July 1994).

44 At 74-75. 
4. All persons have the right to an environment adequate to meet equitably the needs of present generations and that does not impair the rights of future generations to meet equitably their needs.

The rapidity with which constitutional protection for preservation of the environment and its lifesustaining qualities has spread around the world is noteworthy. It began with the Stockholm Declaration in 1972 following the global eco-summit held that year: ${ }^{45}$

Man has the fundamental right to freedom, equality and adequate conditions of life, in an environment of

a quality that permits a life of dignity and well-being, and he bears a solemn responsibility to protect and improve the environment for present and future generations.

Should New Zealand provide constitutional protection for the environment the courts would have increased powers. They could in appropriate cases adjudicate on whether the tests provided in the Constitution have been met. It is a stronger form of judicial review than exists under the powers of judicial review that presently reside in the New Zealand courts. But it is not an appeal on the merits of a decision. It is an adjudication on whether stated constitutional standards have been met in the circumstances. And under the proposals made Parliament would have the last word. ${ }^{46}$

The conclusion for this portion of the article is that standards for environmental protection in New Zealand would increase and the capacity for judicial measurement of the environmental obligations would be enhanced by the proposal. It would give the environment a significant legal voice. Nevertheless, it is important to emphasise that the political policy-makers would still be in control of the fundamental policy parameters, not the courts.

\section{THE WAITANGI TRIBUNAL}

The importance of the Waitangi Tribunal in the context of this article is that it provides a forum for the presentation of an alternative narrative on climate change issues to that contained in the official policy. The same is true of reports from the Parliamentary Commissioner for the Environment made under the Environment Act $1986 .^{47}$

While the recommendations of the Tribunal are not binding upon the government, history shows that its capacity to develop environmental arguments based on the Treaty of Waitangi have had

45 Report of the United Nations Conference on the Human Environment UN Doc A/CONF48/14/Rev1 (1972) at 4 .

46 See Palmer and Butler, above n 39, at ch 19, Constitution Aotearoa, arts 109-111.

47 There were outstanding reports of high quality on climate change made by the Parliamentary Commissioner for the Environment, Dr Jan Wright, that had little impact on government policy. I instance the following: A Zero Carbon Act for New Zealand: Revisiting 'Stepping stones to Paris and beyond' (7 March 2018); Stepping stones to Paris and beyond: Climate change, progress and predictability (27 July 2017); Climate Change and agriculture: Understanding the biological greenhouse gases (19 October 2016); and Changing climate and rising seas: Understanding the science (November 2014). 
persuasive power in a number of situations. The reports are readily available. ${ }^{48}$ An early example was the claim that Te Atiawa brought to the Tribunal in 1981 against a Think Big project. The Māori claim was that untreated sewage and industrial waste from a synthetic fuels plant discharged through the Motonui outfall would pollute traditional fishing reefs. The Tribunal reported clearly in favour of the Māori claims in 1983. The then Government proposed to ignore the claim but was forced to back down after heavy public concern was expressed. The outfall was abandoned. This decision was followed by other reports with an environmental aspect: the Kaituna River and the Manukau Harbour claims. ${ }^{49}$

This is not the place to discuss the detailed arguments on climate change that can be made on the basis of the Treaty to the Tribunal; suffice it to say that claims based on climate change policy deficiencies are already before the Tribunal. ${ }^{50}$ The Treaty of Waitangi Act 1975 gives the Tribunal jurisdiction to entertain claims from Māori. Section 6 currently provides in part:

6 Jurisdiction of Tribunal to consider claims

(1) Where any Maori claims that he or she, or any group of Maoris of which he or she is a member, is or is likely to be prejudicially affected-

(a) by any ordinance of the General Legislative Council of New Zealand, or any ordinance of the Provincial Legislative Council of New Munster, or any provincial ordinance, or any Act (whether or not still in force), passed at any time on or after 6 February 1840; or

(b) by any regulations, order, proclamation, notice, or other statutory instrument made, issued, or given at any time on or after 6 February 1840 under any ordinance or Act referred to in paragraph (a); or

(c) by any policy or practice (whether or not still in force) adopted by or on behalf of the Crown, or by any policy or practice proposed to be adopted by or on behalf of the Crown; or

(d) by any act done or omitted at any time on or after 6 February 1840, or proposed to be done or omitted, by or on behalf of the Crown,-

and that the ordinance or Act, or the regulations, order, proclamation, notice, or other statutory instrument, or the policy or practice, or the act or omission, was or is inconsistent with the principles of the Treaty, he or she may submit that claim to the Tribunal under this section.

The history of the Waitangi Tribunal shows that well-researched analytical reports from the Māori perspective can influence the wider public discourse and policy positions over time. On the Waitangi

48 See Waitangi Tribunal <www.waitangitribunal.govt.nz〉.

49 For a discussion of the development of the Waitangi Tribunal's jurisdiction see Geoffrey Palmer New Zealand's Constitution in Crisis: Reforming our Political System (John McIndoe, Dunedin, 1992) at 78-82.

50 Michael Sharp, Nicole Smith and Tania Te Whenua "Indigenous peoples' climate change claims" (paper presented to 2nd Pacific Climate Change Conference, Wellington, February 2018). 
Tribunal website there are almost 130 reports and a significant number of them have involved analysis of Māori approaches to environmental issues. Whether the Tribunal can make a significant contribution in the climate change space remains to be seen. But it is a voice that should be heard.

\section{CONCLUSION}

This article has advanced a limited number of propositions thought to be necessary if a viable New Zealand legal framework is to be developed to combat climate change.

Climate change is a multifaceted problem that presents unique policy challenges. Solving it depends upon making progress through an inordinately complex set of legal relationships between the development of international norms and domestic legal rules around the world.

The New Zealand domestic legal system and its constitutional arrangements are such that it cannot be reasonably expected as matters stand that the courts can make a significant contribution to nudging policy-makers in the direction of adequately addressing the issues when decisions of government fall short. $^{51}$

The provision of an environmental right in a written, codified constitution would give the courts more capacity than they have now to adjudicate on climate change issues. Despite such a change, the courts would not become principal players in the climate change policy arena. An environmental constitutional right would however change the current balance of forces within the New Zealand legal system and move it towards ensuring that constitutional guarantees for the environment were satisfied in practice. Their role would still revolve around legality and they could be helpful and constructive, but not central.

The Parliamentary Commissioner for the Environment and the Waitangi Tribunal also have the potential to provide alternatives to the official narrative and these could both be helpful in stimulating public opinion to demand more from elected representatives.

The development of a robust legal framework within which New Zealand can address climate change issues that does not result in big public policy fluctuations flowing from general elections should be forged.

An enduring policy framework, with appropriate institutions, is urgently required. Even then there is no guarantee of success, given that all nations need to row in the same boat. But without such a framework there is little prospect of success.

51 Richard H Thaler and Cass R Sunstein Nudge: Improving Decisions About Health, Wealth, and Happiness (Penguin Books, London, 2009) at 193-210. 